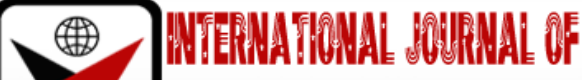

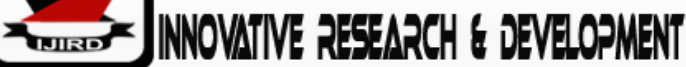

ISSN 2278-0211 (Online)

\section{An Investigation into the Selection of Teaching Methods and Factors Influencing the Selection: A Case of Science Teachers of Berekum Municipality, Ghana}

\author{
Eric Appiah-Twumasi \\ Assistant Lecturer, Department of Educational Studies, \\ Akenten Appiah-Menka Unversity of Skills Training and Entrepreneurial Development, Ghana
}

\begin{abstract}
:
This study investigated some teaching methods used by Science teachers and factors influencing the selection of the teaching method, in the Berekum Municipality, Ghana. The study adopted a descriptive research survey with a 34 sample size composed of Science teachers from the public and private Senior High Schools in the Berekum Municipality. An adapted questionnaire, which was validated using Cronbach's Alpha reliability test with an alpha value of .73 was used to obtain data for the study. The results revealed that the demonstration and observation teaching methods were the most frequently used teaching methods, whiles the generative teaching method was rarely used by the Science teachers. The study findings revealed that gender, class size, examination, professional training, classroom environment, curriculum and teaching experience were the most important factors influencing the selection of teaching methods by the Science teachers. Also, students' personality, students' self-concepts and cultural factors were rated as moderately important factors influencing the selection of teaching methods. However, students' interest, in-service training, student-teacher rapport, ICT and TLM factors were rated as slightly important factors that influence the selection of teaching methods by the Science teachers. While the findings revealed that the selections of teaching methods were not gender-related, the factors influencing the selection of the teaching methods were gender-related. The study recommends that in-service training and workshop should be organised for the Science teachers on how to factor student interest in the selection of their teaching methods.
\end{abstract}

Keywords: Science, teaching methods, factors, influencing, selection

\section{Introduction}

Teaching in general and for that matter, Science teaching is pivoted on three elements. These are the students, the teacher and the subject matter. Out of these elements, the teacher is the most important factor in the teaching and learning process of any quality Science teaching. Thus, Science teachers are seen as the most prominent figures responsible for the teaching and learning process. In Science teaching and learning processes, Science teachers must be able to differentiate their teaching and learning process whether it is a passive teaching and learning or interactive one, which is expected to facilitate student understanding (Rahaku et al., 2018). Therefore, Zawadi (2020) stated that Science teachers should consider what type of teaching methods that they will use in their lessons. Zawadi added that the type of teaching methods employed by the teacher has a significant impact on the student's learning process to ensure quality education. Quality Science teaching is ensured by the method that is most appropriate for attaining specific educational goals for a course (Queensoap et al., 2020).

According to Kizlik (2016), the instructional method, which is right for a particular lesson depends on many factors such as the age and cognitive development of the students, what the students know, and what they must know to succeed in the subject, the subject matter, student interest and objective of the lesson. Kizlik (2016) added that other factors are time, space, materials and resources available, and the kind of interaction between students in the classroom environment. Johnson and Johnson (2010) think that learning environments reflect the overall structure of the learning goals, which in turn largely determines the daily routines, social and emotional condition. They added that learning environments also reflect the moment-to-moment interaction among the teacher and students and the students themselves. Otunga and Nyandusi (2011) are of the view that teachers should use teaching methods, which allow learners to take part in learning. They further argue that learning is best when learners take part and teachers should do everything possible to make teaching and learning interactive. The authors proposed that there is a need for teachers to use appropriate teaching and learning materials and allow the students to interact with the teaching and learning materials so that effective learning may be realised. Therefore, the teacher should be able to make use of different teaching methods according to the circumstances in case their original instructional methods selected fail. However, teaching Science, especially in inadequately equipped classrooms where the teacher has limited teaching resources is a demanding task. 
With these limitations of instructional materials in most schools, Science teachers must consider the classroom reality and should be guided by contextual factors around them while trying to select teaching methods. Unfortunately, most influencing factors are beyond the Science teachers' control, so the Science teachers find it challenging to use some teaching methods in promoting quality education.

Science curriculum is seen as a medium through which any country aims to achieve its industrialisation targets. Consequently, Science teachers must engage students in effective teaching and learning through the selection of appropriate teaching methods if the goals have to be realised. However, most Science teachers do not use teaching methods that would make the curriculum relevant to the students. This emanates from the fact that many Science teachers appear stagnant with teaching methods that do not facilitate student understanding. But, the Ghanaian Science academic curriculum continues to advocate the use of modern approaches to teaching that utilises the student-centered teaching methods. It was against this background that this study was designed to investigate teaching methods mostly employed by the Senior High School Science teachers and the factors influencing the selection of these teaching methods.

\subsection{Research Questions}

The following research questions guided the study:

- What are some of the frequently used teaching methods employed by the Science teachers?

- What is the difference between male and female Science teachers in terms of the most frequently used teaching methods?

- What are the factors influencing the Science teachers' selection of teaching methods?

- What is the difference between male and female Science teachers in terms of factors influencing the selection of teaching methods?

\subsection{Research Hypothesis}

The study was also guided by three hypotheses which were tested at .05 level of significance:

- $\mathrm{H}_{01}$ : There is no statistically significant difference between male and female Science teachers frequently employed teaching methods.

- $\quad \mathrm{H}_{02}$ : Gender has no effect on the Science teachers' selection of teaching methods.

- $\mathrm{H}_{03}$ : Gender has no effect on the Science teachers in terms of factors influencing the selection of teaching methods.

\section{Related Literature}

\subsection{The Nature of Teacher-Centered Teaching Methods}

This type of teaching methods focuses on students' ability to tell, memorise and recall information. Students in a teacher-centered classroom are very restricted because their prime responsibility is reduced basically to asking or answering questions. Characteristically, in the teacher-centered teaching methods, most of the time the students are passive listeners and receive knowledge. The teacher is the center of the processes that go on in the classroom. In the teacher-centered approach to teaching, the teacher is a dispenser of information and a fount of all knowledge. In this view Boison et al., (2009) suggested a picture of students sitting in rows in front of the teacher who is talking and passing information to students with the aid of a blackboard as the students either listen passively or take down notes. Teachers or educators who hold this view see the child's mind as "tabula rasa" or empty slate to be filled with teacher's information. Thus, students are considered as containers and the teacher is the holder of knowledge. The teacher is seen as one who knows what dose of knowledge the child needs, hence makes all the decisions and direction of the teaching and learning process.

In the teacher-centered instructed Science classroom, teachers teach Science concepts through minimal discussion and lecturing. The teacher describes and defines those concepts and writes related equation and keywords on the chalkboard. Students take notes and after the teachers' explanations, the concepts are discussed through teacher-directed questions. Consequently, students in this classroom situation are probably passive learners instead of active learners. In this sense of teaching, the teacher may be seen to be teaching yet may be teaching very little in practical sense. The students may not be learning and even if they are seen learning, they may be learning a pre-digested material, which may fail to develop their growing mental faculty.

\subsection{The Nature of Student-Centered Teaching Methods.}

The current dimension of Science teaching may be seen as a bipolar process, between the teacher and students. Teachers who adopt this classroom interaction are to be seen as facilitators and coaches, a person who assists students to learn for themselves. In the student-centered Science teaching methods, the emphasis is on student's needs, requirement, interest and capability to develop. Characteristically, in the student-centered Science teaching methods, the teacher and students jointly explore the different aspects of the problem. According to Boison et al., (2009), the role of the teacher in student-centered teaching approach is to create a problematic situation, have materials and resources available to the students and help them identify issues. Boison et al added that the teacher should guide students to state hypotheses, test them and actively conclude from inferences. According to Pickering, Marzano and Pollock (2001), active or participatory learning by the students is the more effective, efficient, and superior instruction for teaching and learning because it allows students to get involved in the learning process. The student-centred Science teaching methods implement the principle of "Tell me, I will forget; Show me, I will remember, Involve me, I will understand" by Benjamin Franklin (cited by Saveliev, 
2014). This implies that teaching is not only a matter of imparting or transmitting knowledge to students but getting students involved in the teaching and learning activities that allow students to truly integrate knowledge.

Student-centered teaching method includes inductive teaching and learning, in which students are first presented with challenges (question or problems) and learn the course material in the context of addressing challenges. Inductive methods include inquiry-based learning, case-based instruction, problem-based learning, project-based learning, and discovery learning. According to Douglas and Jaquit (2009), student-centered learning is an approach to teaching that focuses on the needs of the students rather than those involved in the teaching and learning process such as teachers and administrators. Felder and Brent (2009) noted that student-centered teaching methods include cooperative learning, in which students work in teams on a learning task under conditions that assure student-positive interdependence and individual responsibility. This approach has many implications for the design of the curriculum, the course content, and the interactivity of courses. For example, student-centered methods have repeatedly been shown to be superior to teacher-centered approaches to instruction (Felder \& Brent, 2007). The authors stated that student-centered lessons promote short-term mastery, long-term retention, and depth of understanding of course material. They added that acquisition of critical thinking or creative problem-solving skills, the formation of positive attitudes towards the subject being taught, or level of confidence in knowledge or skills are ensured in this learning approach.

\section{Methodology}

\subsection{Research Design}

The study used descriptive survey design using a questionnaire to collect data related to Science teaching methods most frequently used by Science teachers and the factors influencing the selection of these teaching methods. The descriptive survey design was adopted to enable the researcher parsimoniously collect large amounts of data over a short period of time from the Science teachers in the Berekum Municipality, Ghana.

\subsection{Participants}

The sample consisted of 34 Senior High School Science teachers from 3 public and 1 private Senior High Schools in the Berekum Municipality. The sample was purposefully selected to include all males and females Integrated Science teachers in the Berekum Municipality.

\subsection{Research Instrument}

A twenty-four-item-questionnaire of the Likert-scale with two sections were used as research instrument. The first section consisted of seven questions which assess the teaching methods use by Science teachers with options such as very frequent, frequent, occasionally, rarely and never. The second section also consisted of seven questions which assesses factors to consider in selecting Science teaching methods with options such as very important, important, moderate, slightly important and not important. The questions in the research instrument were adapted from Queensoap et al., (2020) and Adhikari (2017). The initial draft of the research instrument was administered to ten (10) Science teachers in the Sunyani Municipality and subjected their responses to are liability test to determine the internal consistency of the items in the questionnaire by using Cronbach's Alpha reliability test. Cronbach's alpha coefficient was .73. According to Kline (2005), alpha value of .90 is considered excellent, .80 very good, and .70 acceptable. Thus, in this study, the observed variables had good internal consistency.

\subsection{Data Analysis}

The data relating to the research questions were analysed using descriptive statistics such as frequencies, percentages, means and standard deviation. Also, t-test and regression analysis were used to test the hypotheses at .05 level of significance.

\subsection{Results of the Study}

- Research Question One: What are some of the frequently used teaching methods employed by Science teachers?

- To answer this research question, mean and standard deviation were used to determine the frequency of use of the Science teaching methods. The interpretation of the use of the frequency of the teaching methods was: 1.00-2.233= rarely used, $2.34-3.66=$ occasionally used, 3.67-5.00= frequently used. Refer to table 1 for the results.

\begin{tabular}{|c|c|c|c|c|}
\hline Teaching Methods & $\mathbf{N}$ & Mean & Std. Dev & Frequency \\
\hline Demonstration & 34 & 3.6741 & 1.4950 & Frequently \\
\hline Observation & 34 & 3.7941 & .9138 & Frequently \\
\hline Project work & 34 & 3.2941 & .9055 & Occasionally \\
\hline Problem-solving & 34 & 2.8824 & .9459 & Occasionally \\
\hline Discovery & 34 & 2.6471 & 1.0697 & Occasionally \\
\hline Generative learning & 34 & 2.2247 & .9941 & Rarely \\
\hline Field trip & 34 & 2.5294 & 1.2609 & Occasionally \\
\hline
\end{tabular}

Table 1: Frequency of Sciences Teachers' Teaching Methods 
As indicated in Table 1, the demonstration method (Mean= 3.6741, $\mathrm{SD}=1.4950$ ) and observation method $(\mathrm{Mean}=3.7941, \mathrm{SD}=.9138$ ) had mean scores ranged between 3.67 and 5.00 and therefore was interpreted as the most frequently used Science teaching methods by the Science teachers. However, the results presented in Table 1 indicate that observational teaching method was the most frequently used teaching by the Science teachers compared to the demonstration method. Also, project work (Mean 3.2941 SD=.9055), problem-solving (2.8824, SD= .9459), discovery (Mean=2.6471, SD=1.0697) and field trip (Mean=2.5294, SD=1.2609) methods had mean scores ranged between 2.34 and 3.66 and were consequently interpreted as occasionally used teaching methods by the Science teachers. Further analyse shows that project work was frequently used teaching method compared to problem-solving, field trip and discovery as presented in Table 1 . The results revealed that the generative teaching method (Mean=2.2247, $\mathrm{SD}=.9941)$ was the rarely used teaching method use by the Science teachers.

- $\quad$ Research Question Two: What is the difference between male and female Science teachers in terms of the most frequently used teaching methods?

To answer this research question mean scores and standard deviation for the males and females Science teachers' selection of teaching methods were computed and used to answer this research question. A higher mean score of males or the females was assumed as a frequently used teaching method by the male and female Science teachers respectively. The results are presented in Table 2.0

\begin{tabular}{|c|c|c|c|c|}
\hline Teaching Method & Gender & Mean & Std. Dev. & Description \\
\hline Demonstration & Male & 3.8800 & 1.3940 & Frequently used by males \\
\hline & Female & 3.0000 & 1.6583 & Less used by females \\
\hline Observation & Male & 3.7600 & .9256 & Less used by males \\
\hline & Female & 3.8889 & .92796 & Frequently used by females \\
\hline Project work & Male & 3.2800 & .84261 & Less used by males \\
\hline Problem-solving & Female & 3.3333 & 1.1118 & Frequently used by females \\
\hline & Male & 2.8000 & .91287 & Less used by males \\
\hline Discovery & Female & 3.1111 & 1.0541 & Frequently used by females \\
\hline & Male & 2.6800 & .9886 & Frequently used by males \\
\hline Generative learning & Male & 2.5556 & 1.3333 & Less used by females \\
\hline & Female & 1.5556 & .52705 & Frequently used by males \\
\hline Field trip & Male & 2.2800 & 1.1000 & Less used females \\
\hline & Female & 3.2222 & 1.4813 & Fress used by males \\
\hline
\end{tabular}

Table 2: Gender Descriptive Analysis of Science Teaching Methods

The results presented in Table 2.0 show that the demonstration method (Mean=3.8800, SD= 1.3940), discovery method (Mean=2.6800, SD=.98826) and generative teaching method (Mean $=2.5200, S D=1.5556)$ were frequently used by the male Science teachers than their female counterparts. However, the results indicate that observation method (Mean= 3.8889, $\mathrm{SD}=$.92796), project work method (Mean=3.3333, $\mathrm{SD}=1.1180)$, problem-solving (Mean=3.1111, $\mathrm{SD}=1.0540)$ and field trip (Mean=3.2222, SD=1.4813) were frequently use by the female Science teachers than their male counterparts.

\subsection{Testing of Hypotheses with Respect to Research Question Two}

- $\mathrm{H}_{01}$ : There is no statistically significant difference between male and female Science teachers frequently employed teaching methods.

To test this hypothesis, an independent sample t-test was performed on the selection of teaching methods by the Science teachers and presented in Table 3.0

\begin{tabular}{|c|c|c|c|c|c|c|}
\hline Teaching Method & Gender & Mean & Std. Dev. & $T$ & $D f$ & Sig.(2-tailed) \\
\hline \multirow[t]{2}{*}{ Demonstration } & Male & 3.8800 & 1.3940 & 1.546 & 32 & .132 \\
\hline & Female & 3.0000 & 1.6583 & & & \\
\hline \multirow[t]{2}{*}{ Observation } & Male & 3.7600 & .9256 & .358 & 32 & .723 \\
\hline & Female & 3.8889 & .92796 & & & \\
\hline \multirow[t]{2}{*}{ Project work } & Male & 3.2800 & .84261 & -.149 & 32 & .882 \\
\hline & Female & 3.3333 & 1.1118 & & & \\
\hline \multirow[t]{2}{*}{ Problem-solving } & Male & 2.8000 & .91287 & .842 & 32 & .408 \\
\hline & Female & 3.1111 & 1.0541 & & & \\
\hline \multirow[t]{2}{*}{ Discovery } & Male & 2.6800 & .9886 & .295 & 32 & .770 \\
\hline & Female & 2.5556 & 1.3333 & & & \\
\hline \multirow[t]{2}{*}{ Generative learning } & Male & 2.5200 & 1.0049 & 2.728 & 2 & $.010^{*}$ \\
\hline & Female & 1.5556 & .52705 & & & \\
\hline \multirow[t]{2}{*}{ Field trip } & Male & 2.2800 & 1.1000 & -2.009 & 32 & $.005^{*}$ \\
\hline & Female & 3.2222 & 1.4813 & & & \\
\hline
\end{tabular}

Table 3: Gender Inferential Statistics on the Frequently Use Science Teaching Method

*Significant at $p<0.05$ 
From the results presented in Table 3, no significant difference was established between the male and female Science in five teaching methods (demonstration, observation, project work, project work and discovery) out of the seven teaching methods under investigation. Specifically, demonstration method[ $\mathrm{t}(32)=1.546$, p $>.05]$, observation methods $[\mathrm{t}(32)=.356, \mathrm{p}>.05]$, project work $[\mathrm{t}(32)=-.149, \mathrm{p}>.05]$, problem-solving $[\mathrm{t}(32)=.842, \mathrm{p}>.05]$ and discovery $[\mathrm{t}(32)=.295$, $\mathrm{p}>.05]$. However, the difference was significant for generative teaching method $[\mathrm{t}(32)=.010$, $\mathrm{p}<.05]$ and field trip [t $(32)$ $=.050, \mathrm{p}<.05]$ in favour of the male and the female Science teachers respectively. In general, non-significant differences were observed in most of the teaching methods used by the Science teachers. Hence, the null hypothesis was retained.

- $\mathrm{H}_{02}$ : Gender has no effect on the Science teachers' selection of teaching methods.

To test this hypothesis, a regression analysis of gender responses on the frequently used teaching method were used. The results are presented in Table 4.

\begin{tabular}{|c|c|c|c|c|c|c|}
\hline $\begin{array}{c}\text { Regression } \\
\text { Analysis }\end{array}$ & $\begin{array}{c}\text { Analysis of } \\
\text { Variance }\end{array}$ & $\begin{array}{c}\text { Sum of } \\
\text { Squares }\end{array}$ & df & $\begin{array}{c}\text { Mean } \\
\text { Square }\end{array}$ & F & Sig. \\
\hline $\mathrm{R}=.5730^{\mathrm{a}}$ & Regression & 2.173 & 7 & .310 & 1.816 & $.127 \mathrm{~b}$ \\
\hline $\mathrm{R}^{2}=.3283$ & Residual & 4.445 & 26 & .171 & & \\
\hline $\mathrm{SE}=.4134$ & Total & 6.618 & 33 & & & \\
\hline
\end{tabular}

Table 4: Regression Analysis of Effect of Gender on the Selection of Science Teaching Methods Dependent variable: Gender

The analysis in Table 4 shows that the independent variable yielded a coefficient of multiple regression (R) of .5730 and adjusted $\mathrm{R}^{2}$ of .3282 . The result implies that $32.82 \%$ of the total variance in the selection of teaching methods by the Science teachers is accounted for by gender. The result in Table 4 further shows that the analysis of variance of the multiple regression data produced F-ratio value of $F(7,33)=1.816$, $p>.05$. Hence, the null hypothesis was retained.

- Research Question Three: What are the factors influencing the Science teachers' selection of teaching methods?

Table 5 shows the mean scores and standard deviations of factors influencing the selection of teaching methods by the Science teachings. The mean scores were used in the graphical representation (see Fig. 1) for easy comparison of results. Mean score greater or above 3 was considered as important or slightly important, respectively, while a mean score of 3 was considered as moderately important

\begin{tabular}{|c|c|c|}
\hline Factors for Consideration & Mean & Std. Dev \\
\hline TLMs & 2.6471 & 1.0410 \\
\hline Classroom environment & 4.1765 & .9991 \\
\hline ICT considerations & 2.7941 & .9464 \\
\hline Class size & 4.3824 & 1.2312 \\
\hline Examination & 4.2353 & 1.3040 \\
\hline Gender considerations & 4.5000 & 1.0224 \\
\hline Curriculum & 4.0000 & 1.1009 \\
\hline Rapport & 2.9118 & 1.2152 \\
\hline Cultural & 3.0294 & 1.3139 \\
\hline Students self-concept & 3.1765 & 1.1926 \\
\hline Student attitude & 2.7059 & 1.0307 \\
\hline Student personality & 3.2941 & 1.1685 \\
\hline Students interest & 2.9118 & 1.0259 \\
\hline Teaching experience & 4.0000 & 1.1281 \\
\hline Professional training & 4.2059 & 1.0084 \\
\hline In-service training & 2.9118 & 1.1110 \\
\hline
\end{tabular}

Table 5: Descriptive Analysis of Science Teaching Methods

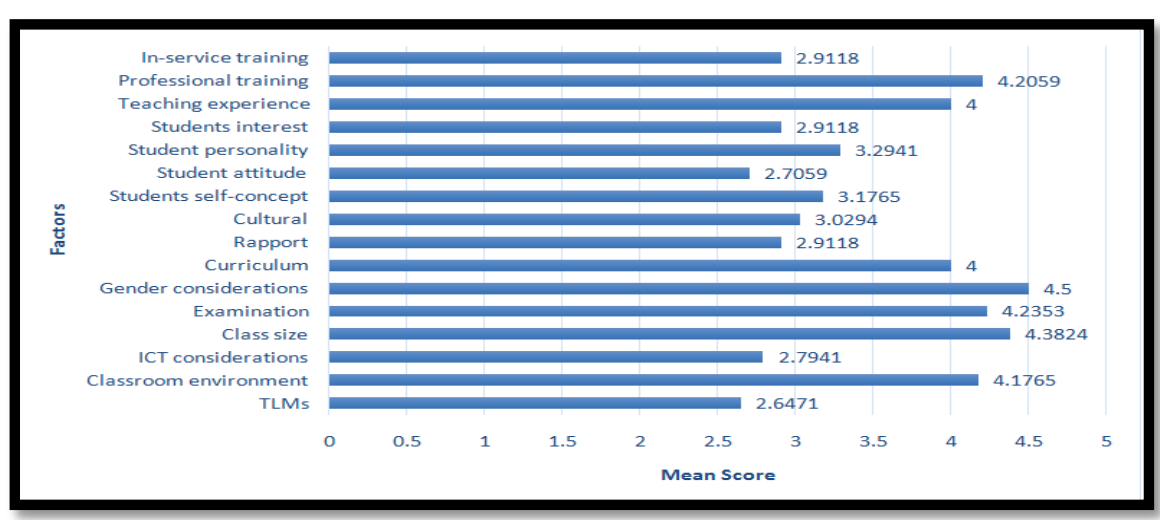

Figure 1: Graphical Representation of Factors Influencing the Selection of Teaching Methods by the Science Teachers 
From Table 5 and Fig. 2, it is noticeable that the mean scores ranged from 2.6471 to 4.5000 . The seven top rating factors influencing the selection of teaching methods starting with the most important factors are gender, class size, examination, professional training, classroom environment, curriculum and teaching experience [mean score: 4.50004.000]. Also, students' personality, students' self-concepts and cultural factors were rated as the moderately important factors for consideration when selecting Science teaching methods [Mean score: 3.2941-3.0294]. However, students interest, in-service training, student-teacher rapport, ICT and TLMs were rated by the respondents as a slightly important factor to consider in selection Science teaching methods [mean scores: 2.9118-2.471].

- Research Question Four: What is the difference between male and female Science teachers in terms of factors influencing the selection of teaching methods?

To answer this research question, mean scores and standard deviation for males and females Science teachers responses on factors influencing the selection of teaching methods were computed and used to answer this research question. A higher mean score of male or that of female was assumed as most influenced factor by the male and female Science teachers respectively. The results are presented in Table 6

\begin{tabular}{|c|c|c|c|}
\hline Factors & Gender & Mean & Std. Dev \\
\hline \multirow[t]{2}{*}{ TLMs } & Male & 2.8000 & 1.0000 \\
\hline & Female & 2.2222 & 1.0929 \\
\hline \multirow[t]{2}{*}{ Classroom environment } & Male & 4.0800 & 1.0770 \\
\hline & Female & 4.4444 & .7264 \\
\hline \multirow[t]{2}{*}{ ICT } & Male & 3.0400 & .9780 \\
\hline & Female & 2.1111 & .3333 \\
\hline \multirow[t]{2}{*}{ Class size } & Male & 4.6000 & 1.0000 \\
\hline & Female & 3.7778 & 1.6414 \\
\hline \multirow[t]{2}{*}{ Examination } & Male & 4.3600 & 1.1135 \\
\hline & Female & 3.8889 & 1.7638 \\
\hline \multirow[t]{2}{*}{ Gender } & Male & 3.8889 & .7371 \\
\hline & Female & 4.7200 & 1.4529 \\
\hline \multirow[t]{2}{*}{ Curriculum } & Male & 4.1600 & .9865 \\
\hline & Female & 3.5556 & 1.3333 \\
\hline \multirow{2}{*}{$\begin{array}{l}\text { Rapport(Student-teacher } \\
\text { relationship) }\end{array}$} & Male & 2.6400 & 1.1503 \\
\hline & Female & 3.6667 & 1.1180 \\
\hline \multirow[t]{2}{*}{ Cultural } & Male & 2.8400 & 1.1789 \\
\hline & Female & 3.5556 & 1.5899 \\
\hline \multirow[t]{2}{*}{ Student self-concept } & Male & 3.1600 & 1.2138 \\
\hline & Female & 3.2222 & 1.2018 \\
\hline \multirow[t]{2}{*}{ Student attitude } & Male & 2.9200 & 1.0376 \\
\hline & Female & 2.1111 & .7817 \\
\hline \multirow[t]{2}{*}{ Student personality } & Male & 3.4800 & 1.2622 \\
\hline & Female & 2.7778 & .6666 \\
\hline \multirow[t]{2}{*}{ Students interest } & Male & 2.7200 & 1.0614 \\
\hline & Female & 3.4444 & .7264 \\
\hline \multirow[t]{2}{*}{ Teaching experience } & Male & 4.2000 & 1.0408 \\
\hline & Female & 3.4444 & 1.2360 \\
\hline \multirow[t]{2}{*}{ Professional training } & Male & 4.4800 & .8717 \\
\hline & Female & 3.4444 & 1.0137 \\
\hline \multirow[t]{2}{*}{ In-service training } & Male & 2.8000 & .9128 \\
\hline & Female & 3.2222 & 1.5634 \\
\hline
\end{tabular}

Table 6: Gender Descriptive Analysis of Factors to Consider in Selecting Science Methods

From Table 6 it is noticeable that the mean scores for the male Science teachers ranged from $4.4800(S D=.8718)$ to $2.6400(\mathrm{SD}=1.1504)$, while the female Science teachers mean scores ranged from $4.7200(\mathrm{SD}=1.4529$ to $2.1111(\mathrm{SD}=.3333)$. The males' top-rated factors which influence their selection of teaching methods were TLMs, ICT, class size, examination, curriculum, students cultural, student attitude, personality and professional training. However, the females' top-rated factors were classroom environment, gender, student self-concept, rapport, in-service training.

\subsection{Testing of Hypothesis with Respect to Research Question Three:}

- $\mathrm{H}_{03}$ : Gender has no effect on the Science teachers in terms of factors influencing the selection of teaching methods.

To test this hypothesis, regression analysis of gender responses on factors to consider in the section of Science teaching method used. The results are presented in Table 7.0 


\begin{tabular}{|c|c|c|c|c|c|c|}
\hline $\begin{array}{c}\text { Regression } \\
\text { Analysis } \\
\end{array}$ & $\begin{array}{c}\text { Analysis of } \\
\text { Variance }\end{array}$ & $\begin{array}{c}\text { Sum of } \\
\text { Squares }\end{array}$ & Df & Mean Square & $\mathbf{F}$ & Sig. \\
\hline $\mathrm{R}=.836^{\mathrm{a}}$ & Regression & 4.626 & 16 & .289 & 2.467 & $.037 \mathrm{~b}$ \\
\hline $\mathrm{R}^{2}=.416$ & Residual & 1.992 & 17 & .117 & & \\
\hline $\mathrm{SE}=.342$ & Total & 6.618 & 33 & & & \\
\hline
\end{tabular}

Table 7: Regression Analysis of Effect of Gender on the Factors for Consideration in

Selecting Science Methods

Dependent Variable: Gender

The analysis in Table 7 shows that the independent variable yielded a coefficient of multiple regression (R) of .836 and adjusted $\mathrm{R}^{2}$ of .416 . The result implies that $41.6 \%$ of the total variance in the factors to consider in selecting Science teaching methods is accounted for by gender. The result in Table 4 further shows that the analysis of variance of the multiple regression data produced F-ratio value of $\mathrm{F}(16,33)=2.46, \mathrm{p}<.05$. Hence, the null hypothesis was rejected.

\section{Discussion of Results}

The results of this study revealed that the most frequently rated teaching methods used by the Science teachers are the observational method (Mean= 3.7941, $\mathrm{SD}=.9138)$ and the demonstration method $(\mathrm{Mean}=3.6741, \mathrm{SD}=.1 .494)$ accordingly. The results as presented in Table 1 further indicate that project work (Mean= 3.2941, SD= .9055), problemsolving (Mean= 2.8824, $\mathrm{SD}=.9459)$ and field trips (Mean $=2.5294, \mathrm{SD}=1.2609$ ) are occasionally used by Science teachers as a method of teaching. However, Generative learning (Mean=2.2647, SD .9941 ) was revealed as the rarely used. Several studies have touted the effects of Generative learning methods on students' development or learning outcomes. For example, Generative learning method increased students' knowledge (Brod et al., 2017), increases cognitive capacity (Miyake et al., 2000, Miller, 2010, Zaitchik et al., 2014), increases students' students' metacognitive ability and increases students metacognitive ability (Schneider 2010, Roebers, 2017).

Therefore, if Science teachers are not using Generative learning method, their students may lack the essential learning outcomes (acquisition of knowledge cognitive capacity and metacognition ability). Similarly, as a constructivist learning approach, student-centered Science teaching methods focus on skills and practices that enable the student to become a lifelong learner of Science and independent problem solver. Contrary, the results suggest that Science teachers are not developing their students' problem-solving skills as are evident in the occasionally used of problem-solving and project- work teaching methods.

Another finding this study discovered was that gender, class size, examination, professional training, classroom environment, curriculum and teaching experience with mean scores ranging between 4.5000 and 4.000 , were important factors to those Science teachers consider the selection of their teaching methods. However, students interest, in-service training, student-teacher rapport, ICT and TLMs were rated as a slightly important factor to consider in selection of teaching methods with mean scores ranging between 2.9118 and 2.471 . One implication that can be drawn from the results obtained concerning the selection factors of ICT and TLMs is that most Science teachers from the respondents do use ICT and appropriate TLMs in their Science teaching methods which is touted as having significant impacts on students learning outcomes, as is evident in their slightly important response.

Concerning gender, the findings suggest that male Science teachers use demonstration, discovery and generative learning methods more frequently in their teaching than female counterparts. Alternatively, it was observed that female Science teachers frequently use observation, project work, problem-solving and filed trips teaching methods more frequently than their male counterparts. Non-significant differences were observed in most of the Science teaching methods used by the teachers, except the generative teaching method, which favoured female Science teachers.

Similarly, on the factors influencing the selection of Science teaching methods, the results revealed that female Science teachers consider all factors relative to the students. Specifically, students' interest, students' self-concepts, students' cultural background and good student-teacher rapport were rated by female Science teachers as factors that influence their selection of teaching methods. This finding affirms the belief that females are portrayed as more nurturing and empathetic, while their male counterparts are portrayed as less emotional and more cognitive. The findings revealed that gender significantly influences the selection of Science teaching methods.

Some aspects of this study are in agreement with previous studies. For example, the result of the current study supports Queensoap et al., (2020) findings that 77\% of the respondents frequently use demonstration methods in teaching. Also, Adhikari (2017) reported that class size, examination and national curriculum influence teachers' selection of teaching methods, which in agreement with study findings.

\section{Conclusion}

This study sought to investigate teaching methods employed by Science teachers and factors influencing the selection of these teaching methods. Following the data collected from the field and the main findings relative to the research questions, many important facts have emerged. As is evident by the results obtained, most Science teachers do not use problem-solving, project work, discovery and generative methods of teaching Science or occasionally use these teaching methods in their teaching. Also, it has emerged from the results that most Science teachers do not consider students' interest in selecting their teaching methods compared to teachers' personal factors, suggesting that they may be using of teacher-centered approach. 


\section{Recommendation}

Based on the results obtained the study recommends that in-service training and workshop should be organised for the Science teachers on how to factor student interest in the selection of their teaching methods.

\section{References}

i. Adhikari, K. (2017). Factors influencing the selection of teaching methods in an efl context. Michigan: Unpublish Thesis.

ii. Boison, G. A., Fosu, W., \& Mensah, A. (2009). Philosophical basis for teaching and learning. Winneba: I.E.D.E, UEW.

iii. Brod, G., Lindenberger, U., \& Shing, Y. L. (2017). Neutral activation patterns during retrieved of schema-related memories: differences and commonality between children and adults. Developmental Science, $20(6), \mathrm{e} 12475$.

iv. Douglas, K., \& Jaquisth, D. (2009). Engaging learners through art making: Choice-base art education in the classroom. New York: Teacher College Press.

v. Felder, R. M., \& Brent, R. (2007). Active Learning: Models from the Analytical Sciences. In P. A. Mabrouk, (ed.) Cooperative Learning., (pp. pp. 34-54). Washington, D. C: American Chemical Society.

vi. Felder, R. M., \& Brent, R. (2009). Active Learning: An introduction. ASQ Higher, 4(5).

vii. Kizlik, B. (2016). Instructional method information: Part 1. Retrieved from http://www.adprima.com

viii. Kline, R. B. (2005). Principle and practice of structural equation modelling (2nd ed.). New

ix. McDermott, L. C., Shaffer, P., \& Somers, M. (2001). Tutorials in introductory Physics. New York: Prentice Hall.

x. Miyake, A., Friedman, N. P., Emerson, M. J., Witzki, A. H., Howerter, A., \& Wager, T. D. (2000). The unity and diversity of executive functions and their contributions to complex "formal lobe" tasks: a latent variable analysis. Cognitive Psychology, 41(1), 49-100.

xi. Otunga, R., \& Nyandusi, C. (2011). The context of curriculum Development in Kenya. Retrieved from http:www.moi university.ac.ke.

xii. Pickering, J. M., \& Pollock, J. (2007). Classroom instruction that works. Research based strategies for increasing students achievement. . Alexandria, VA: Association for Supervision and Curriculum Development.

xiii. Queensoap, M., Dogitimiye, M., Ayebanengimote, V., Gbaye, M., \& Fortune, S. (2020). Assessment of factors influencing lecturers' selection of teaching method in teaching and learning in higher institutions in Bayelsa State. International Journal of Research in Education Humanities and Commerce, 1(1), 19-32.

xiv. Rahaya, T., Syafril, S., Wati, W., \& Wekle, I. S. (2018). Practical of physics through integrated Science student worksheets. International Journal of Pure and Applied Mathematics, 119(18), 1181-1194.

xv. Roebers, C. M. (2017). Executive function and metacognition: towards a unifying framework of cognitive selfregulation. Developmental Review, 45, 31-51.

xvi. Saveliev, M. (2014). Project-base continuous learning. Retrieved from DOI:10.13140/2.1.5106.1121

xvii. Schneider, W. (2010). Metacognition and memory development in childhood and adolescence. In H. S. Water, \& W. Schneider, (Eds.) Metacognition strategy use, and instruction (pp. 54-81). New York: Guilford Press.

xviii. Zaitchik, D., Iqbal, Y., \& Carey, S. (2014). The effect of executive function on biological reasoning in young children: an individual difference study. Child Development, 85(1), 160-175.

xix. Zawadi, L. (2020). Types of the teaching methods, their advantages and disadvantages. Retrieved from https://www.legit.ng/1143440-types-teaching-methods-advantages-disadvantages.html 